\title{
Some identities involving divided differences
}

\section{DAN BĂRBOSU}

\section{ABSTRACT.}

To study approximation properties of linear positive operators various identities involving divided differences are used. The aim of this note is to present two types of such kind of identities. The first one was used by Abel and Ivan [Abel, U. and Ivan, M., Some identities for the operator of Bleimamm, Butzer and Hahn involving divided differences, Calcolo, 36 (1999), 143-160; Abel, U. and Ivan, M., New representation of the remainder in the Bernstein approximation, J. Math. Anal. Appl., 381 (2011), No. 2, 952-956] to derive approximation properties of Bleimann, Butzer and Hahn $(\mathrm{BBH})$ operators from the corresponding properties of the classical Bernstein operators. The second type of identifies can be used to derive some approximation properties of the BBH operators from the properties of some Stancu type operators.

Aknowledgement. The author thanks the referees for their suggestions that contributed to the improvement of the manuscript.

\section{REFERENCES}

[1] Abel, U. and Ivan, M., Some identities for the operator of Bleimamm, Butzer and Hahn involving divided differences, Calcolo, 36 (1999), 143-160

[2] Abel, U. and Ivan, M., New representation of the remainder in the Bernstein approximation, J. Math. Anal. Appl., 381 (2011), No. 2, $952-956$

[3] Agratini, O., Aproximare prin operatori liniari, Presa Univ. Clujeană, Cluj-Napoca, 2001 (Romanian)

[4] Agratini, O., An application of divided differences, Aut. Comp, Appl. Math., 4 (1995), No. 2, 95-99

[5] Aramă, O., Some properties concerning the sequence of polynomials of S. N. Bernstein (Romanian), Studii şi Cerc. (Cluj), 8 (1957), No. 3-4, 195-210

[6] Bărbosu, D., Introducere in analiza numerică şi teoria aproximării, Ed. Universităţii de Nord Baia Mare, 2009 (Romanian)

[7] Bărbosu, D., Acu, A. M. and Sofonea, F. D., The Voronovskaja-type formula for the Bleimann, Butzer and Hahn operators, Creative Math and Inf, 23 (2014), No. 2, 137-140

[8] Bărbosu, D., Two dimensional divided differences revisited, Creative Math.\& Inf., 17 (2008), No. 2, 1-7

[9] Bărbosu, D. and Pop, O. T., On the Bernstein bivariate approximation formula, Carpathian J. Math., 24 (2008), No. 3, 293-298

[10] Bărbosu, D. and Pop, O. T., Bivariate Schurer-Stancu operators revisited, Carpathian J. Math., 26 (2010), No. 1, 24-35

[11] Bleimann, G., Butzer, P. L. and Hahn, L., Bernstein-type operator approximating continuous functions on the semi-axis, Nederl. Akad. Wetensch. Indag. Math., 42 (1980), 255-262

[12] Ivan, M., A note on the Bleimamm, Butzer and Hahn operator, Automat. Comput. Appl. Math., 6 (1997), No. 1, 11-15

[13] Ivan, M., Elements of Interpolation Theory, Mediamira Science Publisher, Cluj-Napoca (2004)

[14] Khan, R. A., A note on a Bernstein-type operator of Bleimamm, Butzer and Hahn, J. Approx. Theory, 53 (1988), 295-230

[15] Mercer, A. McD., A Bernstein-type operator approximating continuous functions on the half-line, Bull. Calcutta Math. Soc., 81 (1989), No. 2, 133-137

[16] Pop, O. T. and Bărbosu, D., Bivariate divided differences with multiple knots, An. Şt. Univ. Ovidius Constanţa, 17 (2009), No. 2, 181-190

[17] Stancu, D. D., The remainder of certain linear approximation formulas in two variables, J. SIAM Numer. Anal. Ser. B., 1 (1964), 137-163

DEPARTMENT OF MATHEMATICS AND COMPUTER SCIENCE

FaCUlty of Sciences North University Center at Baia Mare

TECHNICAL UNIVERSITY OF CLUJ-NAPOCA

VICTORIEI 76, 430122 BAIA MARE, ROMANIA

E-mail address: barbosudaneyahoo.com 